\title{
Corporate websites in Africa: Has online investor relations communication improved during the past four years? Evidence from Egypt, Kenya, Morocco, Nigeria and Tunisia
}

Authors:
Roelof Baard ${ }^{1}$
George Nel ${ }^{1}$
Affiliations:
'Department of Accounting,
University of Stellenbosch,
South Africa
Correspondence to:
Roelof Baard
Email:
rbaard@sun.ac.za
Postal address:
Private Bag X1, Matieland
7602, South Africa
Dates:
Received: 09 Nov. 2010
Accepted: 07 Apr. 2011
Published: 04 July 2011
How to cite this article:
Baard, R. \& Nel, G., 2011,
'Corporate websites in Africa:
Has online investor relations
communication improved
during the past four years?
Evidence from Egypt,
Kenya, Morocco, Nigeria
and Tunisia', SA Journal of
Information Management
13(1), Art. \#460, 7 pages.
doi:10.4102/sajim.v13i1.460

(C) 2011. The Authors. Licensee: AOSIS OpenJournals. This work is licensed under the Creative Commons Attribution License.
Background: Investors require detailed financial and nonfinancial information to evaluate investments. This information is available in various forms (e.g. hard copies, published media, broker and investment consultants and corporate websites). Corporate websites have the potential to be both a one-stop-shop for investor needs and an efficient cost-effective medium for companies to communicate with investors. As previous research (Baard \& Nel 2006) showed unacceptable low levels of Internet presence in selected African countries compared to other international companies, including companies in South Africa, a follow-up study was undertaken. An improvement was expected given the rapid increase in Internet users, improvements in infrastructure, the arrival of wireless access technologies and lower tariffs.

Objectives: The objectives of this study were to measure the availability of corporate websites and dedicated investor relations (IR) sections; to evaluate the content of IR information communicated and to compare findings with previous research.

Method: For ease of comparison this study has evaluated the same 40 companies in each of the countries, namely Egypt, Kenya, Morocco, Nigeria and Tunisia that were evaluated in the 2006 study. A number of steps were taken to find the websites after which all the working websites were screened and evaluated against a checklist of international best practices.

Results: Although improvements were apparent, 19\% of the companies in the study still do not have websites, $20 \%$ do not supply financial information on websites and a significant number of companies do not optimally utilise websites according to international best practices.

Conclusion: Notwithstanding improvements, a significant number of companies do not optimally utilise their corporate websites to communicate to investors. Possible reasons were discussed (e.g. necessary skills, available technology and cost), but it was concluded that companies are probably either negligent, do not regard it as important to communicate information to investors via corporate websites, or do not realise the benefits of communicating company information in this manner.

\section{Introduction}

According to the 2009 World Bank Annual Report 50.9\% of the population in Africa are living on less than $\$ 1.25$ a day. It is regularly argued that increased foreign direct investments (FDI) are required to fight poverty. One type of FDI comprises investment by investors in existing companies. To evaluate such a potential investment, investors require detailed financial and nonfinancial information. This information is available in various forms (e.g. hard copies, published media, broker and investment consultants and corporate websites).

Corporate websites as an information source could potentially, if optimally used, have advantages for both investors and companies. For investors they could be an easy, quick, cheap, complete and up-to-date source of information that is readily available. For companies it will reduce the cost of and the time required for distributing information and will enable them to communicate with previously unidentified potential investors (FASB 2000).

Makinson Cowell in 2000 found that up to $75 \%$ of institutional investors review corporate websites before meeting a company's management. More recent research by the US Securities and Exchange Commission (SEC 2008) has found that $5 \%$ of retail investors said they completely 
rely on information from the Internet, $25 \%$ said they regularly relied on it to guide their investment decisions, and $26 \%$ said they rely on it a little. Investors who accessed information over the Internet to guide their investment decisions were asked where they go on the internet to get that information. The most often mentioned sources were individual company websites $(38 \%)$ and financial investment information websites (24\%; SEC 2008).

The SEC research showed that $21 \%$ of retail investors use websites as an information source. One possible reason for the discrepancy between the Makinson Cowell (2000) and the SEC (2008) research could be that retail investors will in general be more dependant on broker and investment consultants as information source compared to institutional investors.

On 01 August 2008 the SEC issued a document to provide guidance to companies regarding the use of company websites under the exchange act. In this document, the SEC states:

we have reached the point where the availability of information in electronic form - whether on EDGAR or a company website - is the superior method of providing company information to most investors, as compared to other method.

(Harrington \& Badian 2009, p. 25)

According to Robert Seberger, president of Investor Relations Marketing, the 'Big Four' components of corporate websites are investor relations (IR), public relations, employment and 'about us' information (Investor Relations Marketing 2006). Marston (1996) defines IR as the link between a company and the financial community by which information for evaluating the company is provided to the financial community (investors). Given this definition of IR, it is clear that investors will be particularly interested in the IR section when visiting a corporate website.

A study undertaken into the top 100 companies in the USA in 2000 revealed that 99 had websites and 93 made provision for investor relations (FASB 2000). A study by Allam and Lymer (2002), on the 50 largest companies in the USA, UK, Canada, Australia and Hong Kong, concluded that $99.6 \%{ }^{1}$ of these companies had websites and $100 \%$ of the companies with websites had investor relations sections.

According to research by Venter (2002), 85 of the top 100 companies in South Africa had active websites and 83 of the 85 companies had some form of investor relations or a financial information web page. Research by Loxton (2003) and Nel (2004) showed similar results. Baard and Nel (2006) showed that the 40 largest companies in South Africa all had working websites with a dedicated IR section in 2006. This, however, was not representative of the rest of Africa, as this research also showed that only $133(67 \%)$ of the largest 200 companies in Egypt, Kenya, Morocco, Nigeria and Tunisia had working websites in 2006. Of these 133 companies with working websites, only 38 had a dedicated IR section and only 57 supplied some financial information (Baard \& Nel 2006). Of the 38 companies with dedicated IR sections only

1.The study conducted was in total on 250 of which 249 had websites.
30 supplied financial information. Of the 200 companies investigated only $87(44 \%)$ therefore supplied financial information.

More recent research by Africanir (2010) showed that 329 (77\%) of 427 companies investigated in 10 African countries (Ghana, Mauritius, Malawi, Nigeria, Namibia, Kenya, Uganda, Tanzania, Zambia and Zimbabwe) had corporate websites. Only $128(30 \%)$ of the 427 companies showed financial information.

Although the percentage of companies with corporate websites according to the Africanir research in 2010 was $10 \%$ higher compared to the 2006 research by Baard and Nel, the percentage of companies that actually display online financial information was $14 \%$ lower in the 2010 research ( $30 \%$ compared to $44 \%$ ). It should however be noted that the 2006 research is not comparable with the 2010 research for the following reasons:

- Difference in market capitalisation of companies included in the 2006 research compared to the 2010 research. In the 2010 research, $60 \%$ of companies had a market capitalisation of less than $\$ 50$ million compared to $22.5 \%$ of companies in the 2006 research.

- Internet presence of countries included in the 2006 research compared to the 2010 research. The 5 countries included in the 2006 research represent around $60 \%$ of internet users in Africa compared to the 10 countries from the 2010 research that represent around 32\% (Internet World Stats 2010).

Although the Internet penetration rate in Africa was only $6.8 \%$ in 2009 , compared to $26 \%$ for the world, it has improved from $2.6 \%$ (2005) to $4 \%$ (2006) and to $6.8 \%$ in 2009 . Internet users in Africa increased from 22 million in 2006 to 67 million in 2009 (Business wire 2006; Internet World Stats 2010).

Given the rapid increase in Internet users, improvements in infrastructure, the arrival of wireless access technologies, lower tariffs and the absence of comparable research after 2007 a follow-up study of the 2006/2007 researches was undertaken.

Following the 2006 study, Baard and Nel (2007) developed a checklist based on previously published best practices (Investor Relations Society 2006) to evaluate the actual content of the IR information communicated via corporate websites. The IR sections of the aforementioned 38 companies were evaluated and compared with the 40 largest companies in South Africa. Although not all the companies evaluated from South Africa supplied all the information required by best practices, the South African companies scored considerably higher in all categories, compared to their Egyptian, Kenyan, Moroccan, Nigerian and Tunisian counterparts. Because the 40 largest companies in South Africa in 2006/2007 all had corporate websites with dedicated investor relation's sections and that their content mostly complied with best practices, this follow-up study only focused on the 40 largest companies in Egypt, Kenya, Morocco, Nigeria and Tunisia. 
The objectives of this study were to:

- measure the availability of corporate websites

- measure the availability of a dedicated IR section on corporate websites

- evaluate the content of investor relations information communicated via corporate websites against a checklist of best practice guidelines for the content thereof

- compare the availability and content of IR sections against 2006/2007 findings.

\section{Gathering the data Selection of companies}

For ease of comparison this study has evaluated the same 40 companies in each of the countries, namely Egypt, Kenya, Morocco, Nigeria and Tunisia that were evaluated in the 2006 study. The companies evaluated in the 2006/2007 study were selected as follows: Firstly, the largest 1000 African companies were sorted according to market capitalisation to establish the largest 200 companies in Africa. In view of the fact that South African companies represented 52\% of the 200 largest companies in Africa, South African companies were removed from this list to avoid skewing of results toward South Africa. After removing South African companies, only Egypt, Kenya, Morocco, Nigeria and Tunisia were found to have more than 10 companies each in the top 200. The 40 largest companies in each of the countries (Egypt, Kenya, Morocco, Nigeria, South Africa and Tunisia) were subsequently selected (Baard \& Nel 2006).

\section{The checklist}

To achieve objectives three and four, this study used the same checklist that was developed and used in the 2007 (Baard \& $\mathrm{Nel})$ study. The contents of the checklist will be discussed in the following section.

\section{Company information}

This entails information about the company from an investment perspective. Suggested ways to provide this information include an 'About us' section, detailed fact books or short one- to two-page fact sheets and management profiles (e.g. interviews, speeches and videos to explain the company, its strategy and the management's vision).

\section{Financial data}

Investors need financial data to quantify the expected returns and risks of an investment in a company. Although financial data primarily consist of the annual report (all the financial statements, director's and auditor's report), best practices include 14 key points to consider for the inclusion of financial data. These key points include:

- an archive of annual reports

- key financial ratios

- relevant information on main intangibles (including those not shown on the balance sheet) dividend history

- share price history

- financial presentations

- key performance indicators (both financial and nonfinancial).

\section{Relevant news}

The purpose of relevant news is to keep investors up to date with news about the company, its strategy and operating environment. It is regarded as important to have a central point of access to all news releases about the company.

\section{Shareholder information}

Best practice proposes a dedicated shareholder information section. This section should provide information on shareholder meetings; important dates for shareholders; contact details of company advisors; and share price movements and announcements. It should also facilitate shareholder administration, either by online management of shareholder information or by providing the information and relevant documentation for investors to download.

To enable current and potential investors to obtain information about the company or its shares, contact details for the investor relations officer or team responsible for shareholder communication should also be provided.

\section{Bondholder information}

Companies should provide clear information on their corporate debt situation and should include information such as credit ratings, terms of banking covenants and contact details for investors with queries relating to the debt situation.

\section{Corporate governance}

Directors manage companies on behalf of shareholders. Corporate governance gives information on how a company is managed. According to the Investor Relations Society's best practice guidelines, a corporate website should reflect the importance of corporate governance for investors by identifying this in the main investor index. Websites should therefore provide a section dedicated to corporate governance (Investor Relations Society 2006).

This section should include information about the company (such as its strategy, vision, products and services that it supplies and current changes), its directors (biographical details, appointment, remuneration, and their interest in the company and share transactions) and the audit committee.

\section{Corporate responsibility}

The corporate website should contain information about the company's corporate responsibility policies and data. Corporate responsibility includes all environmental, social, health and safety issues and the management of risks across the company.

Possible information that could be supplied includes details of individual(s) responsible for such policies, internal arrangements for implementation of these policies, a statement of specific policies (such as energy consumption, recycling of waste, carbon dioxide emissions, etc.) and policy objectives (e.g. maximum carbon dioxide emissions per annum). 


\section{Methodology followed in gathering the data}

\section{Availability of corporate websites (first objective)}

A number of steps were taken to find the websites. The list of names of the relevant companies in the different countries was obtained and the first step was to enter the company names from the list into two search engines, namely Google (http://www.google.com) and Yahoo (http://www.yahoo. com). Only the first 50 results from each search engine were evaluated. If the URL of the company website was displayed in the first 50 results, the site was visited to gather the required information. When a technical error occurred, for instance if the site was under construction or there was a failure to access the site, that site was visited again on the following day to gather the required information.

When a particular company website could not be found on the first 50 results from any of the two search engines, certain websites containing company profiles and corporate information of various companies were used to try and find the company websites. The usage of these websites was made difficult in that some of these websites would only supply the relevant company information at a price, for instance (http://www.mbendi.co.za). There are websites that were used to find the company websites that did supply the information at no cost, to help find company websites that are not promoted on the first 50 results from the two search engines. These websites are (http:/ / www.business.com) and (http://goliath.ecnext.com).

\section{Availability of dedicated investor relations sections (second objective)}

The working corporate websites that were found were subsequently screened for Investor Relations. When no Investor Relations section could be found, the websites were screened for any other financial information (e.g. financial statements).

\section{Evaluating the content of investor relation information communicated (third objective)}

The content presented on websites of companies offering dedicated investor relations sections were evaluated using the discussed checklist. Given the magnitude of the present study (200 companies were investigated); it was decided to only investigate the content of IR information that was communicated by corporate websites that had dedicated IR sections (69 companies). This study was also based on the underlying assumption that companies with dedicated IR sections on their corporate websites would on average communicate better with investors via their websites and therefore comply better with best practices.

Time spent to evaluate IR sections was limited to 15 minutes per company. The rationale behind this was that important information should be easily available and at first glance to users of corporate websites. If specific information could not be found, the search facility, if available, was used.
Although all the websites of the companies investigated in this section have investor relations sections and all the information included in the checklist was of an investor relations nature, it is not a best practice to group all investor relations communication under the investor relations section. To complete the checklist, both the dedicated investor relations section and the remainder of the corporate website were therefore investigated.

Best practice guidelines for content suggest a central point for relevant news and dedicated sections for shareholder information, corporate governance and corporate responsibility. The corporate websites of companies in this section that did not have dedicated sections for the items of information listed earlier were also screened for the availability of bits and pieces of such information, either under the investor relations section or in the remainder of the website including annual reports.

During the evaluation it was accepted that different companies, and especially different countries, would use different terminology for the different elements investigated. The following are examples of different names used for the different elements of the checklist:

- Company information: About us

- Relevant news: Media centre, news, news and media, pressroom

- Shareholder information: Equity shareholders, shares, share information

- Bondholder information: Credit rating, debt investors

- Corporate responsibility: Sustainability, sustainability reports, sustainable development, global reporting initiative, corporate social investment, social, policies, corporate citizenship.

It should also be noted that the quality and completeness of the information supplied was not evaluated in this study. As discussed, shareholder information should, for example, include information about shareholder meetings, important dates for shareholders, contact details of company advisors and share price movements and announcements. It should also facilitate shareholder administration, either through online management of shareholder information or by providing the information and relevant documentation for investors to download. If a company supplied only one element of shareholder information, for example, share price movements, it was taken that shareholder information was supplied and the checklist was marked.

\section{Results}

\section{The availability of corporate websites (first and fourth objective)}

In the 2006 study only $67 \%$ of the 200 companies investigated had working websites. Although this position has increased to $81 \%$ (see Table 1) it is still very disappointing for the following reasons: 
- The companies evaluated were the top 40 companies in each country and the average market capitalisation of companies with no websites were over $\$ 350$ million in $2006 / 2007$

- The relatively low cost of developing and managing a corporate website

- The Internet presence of the countries involved, as they are all amongst the top ten internet companies in Africa and represent around $60 \%$ of all internet users in Africa.

\section{Availability of dedicated investor relations sections (second and fourth objective)}

As anticipated from the reported increase in working corporate websites, the number of websites with dedicated IR sections increased accordingly. It should be noted however, that $44 \%$ of the websites now have a dedicated IR section compared to $29 \%$ in 2006 (see Table 2). As a result, the percentage of websites that presented no IR section but some financial information decreased from $43 \%$ to $36 \%$. An alarming $20 \%$ of all companies with working websites still do not supply any financial information on their websites.

\section{Evaluating the content of communicated investor relations information (third and forth objective)}

It is evident from Table 3 that the dedicated IR sections of companies evaluated in 2010 improved in all categories (except for financial reports - archive) after the 2007 study. It should be noted that 69 companies were evaluated in 2010 , compared to the 38 evaluated in 2007, these being the companies that had dedicated IR sections on their corporate websites in the respective studies. The results of each section in Table 3 are briefly discussed in the section after Table $3 .^{2}$

\section{Company information}

In 2010, all companies communicated information about themselves on their corporate websites compared to $92 \%$ in 2007. This is mainly performed by means of an 'About Us' section on the corporate website, where various kinds of information about the company are communicated.

\section{Financial Data: Annual reports and archive}

Although $93 \%$ of the companies supplied financial statements on their corporate websites and nearly all of this information is available under the IR section, which represents an $18 \%$ improvement since 2007, the percentage of companies that supplied archive financial reports as well as the average archive years for which these reports were supplied decreased from 2007 to 2010. In total, five companies with dedicated investor relations sections have not supplied annual reports on their corporate websites. Nineteen companies $(28 \%)$ are not supplying any archive annual reports on their corporate websites. This is not satisfactory, as one would expect that a listed company would at least have its annual report and archive of annual reports available to investors on the corporate website.

\section{Relevant news}

Three companies (4\%) did not communicate any relevant company news, compared to 2007 when $10.5 \%$ (4 companies)

2.It must be noted that the information on the corporate websites of nine Tunisian companies was only available in French.

TABLE 1: Availability of corporate websites.

\begin{tabular}{|c|c|c|c|c|c|c|c|c|c|c|c|c|c|}
\hline \multirow[t]{3}{*}{ Availability } & \multirow[t]{3}{*}{ Year } & \multicolumn{12}{|c|}{ Countries } \\
\hline & & \multicolumn{2}{|c|}{ Egypt } & \multicolumn{2}{|c|}{ Kenya } & \multicolumn{2}{|c|}{ Morocco } & \multicolumn{2}{|c|}{ Nigeria } & \multicolumn{2}{|c|}{ Tunisia } & \multicolumn{2}{|c|}{ Total } \\
\hline & & $n$ & $\%$ & $n$ & $\%$ & $n$ & $\%$ & $n$ & $\%$ & $n$ & $\%$ & $N$ & $\%$ \\
\hline \multirow[t]{2}{*}{ Working website } & 2006 & 25 & 62.50 & 28 & 70.00 & 30 & 75.00 & 32 & 80.00 & 18 & 5.00 & 133 & 67.00 \\
\hline & & 30 & 77.00 & 35 & 88.00 & 30 & 79.00 & 34 & 89.00 & 29 & 73.00 & 158 & 81.00 \\
\hline \multirow[t]{2}{*}{ No website } & 2006 & 7 & 17.50 & 11 & 27.50 & 6 & 15.00 & 6 & 15.00 & 22 & 55.00 & 52 & 26.00 \\
\hline & 2010 & 4 & 10.00 & 4 & 10.00 & 5 & 13.00 & 2 & 5.00 & 10 & 25.00 & 25 & 13.00 \\
\hline \multirow[t]{2}{*}{ Failed to access } & 2006 & 6 & 15.00 & 1 & 2.50 & 4 & 10.00 & 1 & 2.50 & - & - & 12 & 6.00 \\
\hline & 2010 & 4 & 10.00 & - & - & 1 & 3.00 & 2 & 5.00 & - & - & 7 & 4.00 \\
\hline \multirow[t]{2}{*}{ Under construction } & 2006 & 2 & 5.00 & - & - & - & - & 1 & 2.50 & - & - & 3 & 2.00 \\
\hline & 2010 & 1 & 3.00 & 1 & 2.00 & 2 & 5.00 & - & - & 1 & 3.00 & 5 & 3.00 \\
\hline
\end{tabular}

$n$, Given as means of number

$N$, Given as means of total number.

TABLE 2: Provision for investor relations on existing working corporate websites.

\begin{tabular}{|c|c|c|c|c|c|c|c|c|c|c|c|c|c|}
\hline \multirow[t]{3}{*}{ Investor relations } & \multirow[t]{3}{*}{ Year } & \multicolumn{12}{|c|}{ Countries } \\
\hline & & \multicolumn{2}{|c|}{ Egypt } & \multicolumn{2}{|c|}{ Kenya } & \multicolumn{2}{|c|}{ Morocco } & \multicolumn{2}{|c|}{ Nigeria } & \multicolumn{2}{|c|}{ Tunisia } & \multicolumn{2}{|c|}{ Total } \\
\hline & & $n$ & $\%$ & $n$ & $\%$ & $n$ & $\%$ & $n$ & $\%$ & $n$ & $\%$ & $N$ & $\%$ \\
\hline \multirow{2}{*}{$\begin{array}{l}\text { Investor relations } \\
\text { section }\end{array}$} & 2006 & 14 & 56.00 & 8 & 28.50 & 6 & 20.00 & 9 & 28.00 & 1 & 6.00 & 38 & 29.00 \\
\hline & 2010 & 19 & 63.00 & 17 & 49.00 & 12 & 40.00 & 21 & 62.00 & - & - & 69 & 44.00 \\
\hline \multirow{2}{*}{$\begin{array}{l}\text { No investor relations } \\
\text { section, but some } \\
\text { financial information } \\
\text { is supplied }\end{array}$} & 2006 & 3 & 12.00 & 15 & 53.50 & 17 & 57.00 & 14 & 44.00 & 8 & 44.00 & 57 & 43.00 \\
\hline & 2010 & 2 & 7.00 & 14 & 40.00 & 14 & 47.00 & 9 & 26.00 & 18 & 62.00 & 57 & 36.00 \\
\hline \multirow{2}{*}{$\begin{array}{l}\text { No investor relations } \\
\text { section and no } \\
\text { financial information }\end{array}$} & 2006 & 8 & 32.00 & 5 & 18.00 & 7 & 23.00 & 9 & 28.00 & 9 & 50.00 & 38 & 29.00 \\
\hline & 2010 & 9 & 30.00 & 4 & 11.00 & 4 & 13.00 & 4 & 12.00 & 11 & 38.00 & 32 & 20.00 \\
\hline
\end{tabular}

$n$, Given as means of number.

$N$, Given as means of total number. 
TABLE 3: Investor relations information communicated evaluated against the checklist.

\begin{tabular}{|c|c|c|c|c|}
\hline \multirow[t]{3}{*}{ Investor relations information } & \multicolumn{4}{|c|}{ Years } \\
\hline & \multicolumn{2}{|c|}{2007} & \multicolumn{2}{|c|}{2010} \\
\hline & $n$ & $\%$ & $n$ & $\%$ \\
\hline Company information & 35 & 92 & 69 & 100 \\
\hline Dedicated section - About us & 35 & - & 69 & - \\
\hline Financial-Annual reports & 30 & 79 & 64 & 93 \\
\hline Dedicated section ${ }^{a}$ & 29 & - & 61 & - \\
\hline Remainder of website & 1 & - & 3 & - \\
\hline Financial - Reports archive & - & - & - & - \\
\hline Annual reports - Archive & 29 & 76 & 50 & 72 \\
\hline Archive - Years & 4.4 & - & 4.1 & - \\
\hline Relevant news & 34 & 89 & 66 & 96 \\
\hline Dedicated section & 32 & - & 64 & - \\
\hline Remainder of website & 2 & - & 2 & - \\
\hline Shareholder information & 27 & 71 & 56 & 81 \\
\hline Dedicated section & 26 & - & 54 & - \\
\hline Website & 1 & - & 2 & - \\
\hline Bondholder information & 9 & 24 & 19 & 28 \\
\hline Dedicated section & 9 & - & 15 & - \\
\hline Website & 0 & - & 4 & - \\
\hline Corporate governance & 32 & 84 & 68 & 99 \\
\hline Dedicated section & 15 & - & 31 & - \\
\hline Remainder of website & 17 & - & 37 & - \\
\hline Corporate responsibility & 21 & 55 & 58 & 84 \\
\hline Dedicated section & 18 & - & 54 & - \\
\hline Remainder of website & 3 & - & 4 & - \\
\hline
\end{tabular}

$n$, Given as means of number.

a, Dedicated section implies that information was communicated through either a dedicated section or under the investor relations section.

did not comply with this best practice. The current study found that 64 companies (out of 66 that do supply relevant news) communicate relevant company news via a central point $(93 \%)$ on the corporate website, giving the investor easy access to relevant news about the particular company.

\section{Shareholder information}

The overall number of companies that supplied shareholder information has improved by $14 \%$ from $71 \%$ in 2007 to $81 \%$ in 2010. This means that 13 companies (19\%) with investor relations sections are not communicating any shareholder information. In $2010,78 \%$ of the evaluated companies supplied shareholder information, either under a dedicated section or under the investor relations section, compared to $68 \%$ in 2007. The remaining companies communicate shareholder information by supplying bits and pieces of information in various sections of their corporate websites, making it harder for the investor to find the required information.

\section{Bondholder information}

Although the availability of bondholder information increased slightly, from $24 \%$ in 2007 to $28 \%$ in 2010 , it is still very low. Some bondholder information, for example debt ratios, can be calculated from annual reports, but other types of bondholder information, for example credit ratings, must be supplied specifically. The study found that, when companies do communicate bondholder information, it is mainly available under the investor relations section of the corporate website.

\section{Corporate governance}

Although nearly all companies (with the exception of one) supply this information, only $45 \%$ of companies have supplied the information under a dedicated IR or corporate governance section. The remaining 55\% supplied the information through the rest of the website, resulting in information being scattered, making it harder for the investor to find the required corporate governance information. The overall number of companies that supplied corporate governance information has also improved, from $84 \%$ in 2007 to $99 \%$ in 2010.

\section{Corporate responsibility}

Companies that supply corporate responsibility information have increased significantly, from $55 \%$ in 2007 to $84 \%$ in 2010. The companies that do communicate this type of information mostly have a dedicated section for it on their corporate websites. Nearly $93 \%$ of the companies supply the information under a dedicated section. This is still much better compared to $55 \%$ of corporate governance information that is scattered around the website.

\section{Conclusion}

To evaluate an investment, investors require detailed financial and nonfinancial information. Although this information is available from various sources, corporate websites have some definitive advantages compared to more traditional source of information. Corporate websites are however not only about investment information, but also cater for the information needs of existing and potential clients and employees. In order to enable investors to obtain the relevant information that they need from corporate websites best practise website guidelines recommend a dedicated IR section that will act as a one-stop-shop for all investor needs.

As an absolute minimum, each company should have a corporate website to start with. This study found that only $81 \%$ of the companies investigated currently had working websites, compared to $67 \%$ in 2006 . This result is surprising, as these companies are the top 40 companies in five of the larger economies in Africa. Of the $81 \%$ of companies with corporate websites, only $80 \%$ made use of a dedicated IR section or provided scattered financial information without a dedicated IR section. If someone would therefore be interested in investing in the top 40 companies in each of Egypt, Nigeria, Morocco, Kenya and Tunisia, relevant online financial information would only be found for 126 or $63 \%$ of the 200 companies. The remaining 74 or $37 \%$ of the companies will either have no corporate website or no relevant information on their corporate websites to assist investors. Furthermore, of the companies with dedicated IR sections on their corporate websites, five and nineteen respectively do not supply annual reports or archive annual reports. Given the importance of annual reports to investors, it is unacceptable for companies, and especially companies of the size investigated in this study, not to supply annual reports on their websites.

Having a corporate website or, even better, a dedicated IR section, does not necessarily guarantee that the corporate website will contain all the relevant information that the investor needs. Best practices that have been developed ensure that IR information communicated to investors contains at least the following information: 
- company information

- financial data

- relevant news

- shareholder information

- bondholder information

- information on corporate governance and corporate responsibility.

Although the availability of this information has improved drastically since 2007, information on corporate governance is still not supplied under a dedicated section, as prescribed by best practices. In the case of $55 \%$ of the companies, corporate governance information is scattered through the website, which makes it very hard for the investor to find the required information. It is not only much more user friendly to have all relevant information gathered under one heading; it also decreases the risk of investors missing important pieces of information.

Notwithstanding the aforementioned improvements, a significant number of companies still do not optimally utilise their corporate websites to communicate to investors.

Possible reasons for the disappointing results recorded could involve a lack of the necessary skills or of available technology to develop and manage corporate websites. Companies may also have the perception that African investors, especially, do not use the Internet to find company information before making decisions. These reasons, however, may no longer be relevant, given the increase in Internet users and bandwidth availability over the past decade.

Cost cannot be a limiting factor (Baard \& Nel 2006) as the average market capitalisation of the companies with no corporate websites reported in the study was in excess of $\$ 350$ million. The costs associated with developing and hosting a corporate website is low compared to the perceived benefits of having a corporate website that communicates all the relevant information. A corporate website allows a company to communicate company information in a manner that is far cheaper, more flexible and more immediate than conventional communication media, like hard copies of information or the printed media.

The only remaining reasons that the authors of this study are able to offer for these poor results from companies in terms of information communicated, are that these companies are either negligent, do not regard it as important to communicate information to investors via corporate websites, or do not realise the benefits of communicating company information in this manner.

The AIC (Africa Investor Relations) sponsors annual online investor relations awards to reward pioneers in this field in Africa. As legislation and regulation in most African capital markets are not as strict as those in other markets and corporate liability not as high, progressive investor relations practices are not as prevalent. According to the AIC there is currently an enormous potential in Africa to build an online relationship and communications with investors (Online investor relations awards 2009). The winner in the category, best online IR programme 2009, was African Sun Limited.

Further research should be conducted to determine the reason(s) for the lack of corporate websites and compliance by companies with best practices of communicating information via corporate websites. Similar research as conducted by the SEC on the use of investors of the internet and more specific corporate websites would also be useful in the future development of capital markets in Africa. A recent post on an AIC Blog reads as follows: 'I read a study by the SEC on US investors and it got me thinking how none of the African markets have anything similar' (AIC Blog 2010).

\section{References}

AIC Blog, 2010, Brief profile of US investors and Africa, viewed 01 February 2010, from http://www.africanir.com/2010/01/01/brief-profile-of-us-investors-and-africa/

Africanir, 2010, IR research: profiling sub-Saharan small caps, viewed 01 March 2010, from http://www.africanir.com/2010/02/07/ir-research-profiling-sub-saharan from hall-caps/

Allam, A. \& Lymer, A., 2002, 'Developments in Internet financial reporting: review and analysis across five developed countries', in Birmingham Business School, viewed 30 September 2003, from http://business.bham.ac.uk/bbs/static/page983.htm

Baard, R.S. \& Nel, G.F., 2006, 'Using corporate websites to market to investors in Africa', South African Journal of Information Management 8(3), viewed 01 November 2009, from http://www.sajim.co.za

Baard, R.S. \& Nel, G.F., 2007, 'Do corporate Web sites in Africa communicate investor information according to best practice guidelines?' South African Journal of Information Management 9(3), viewed 01 November 2009, from http://www. sajim.co.za

Business Wire, 2006, Internet penetration in Africa reached $4 \%$ in 2006, up from $2.6 \%$ on the previous year, viewed 01 February 2010, from http://findarticles.com/p/ on the previous year, viewed 01 February 2010, from
articles/mi_m0EIN/is_2006_May_8/ai_n16347551/

FASB, 2006, Electronic distribution of business reporting information: Financial Accounting Standards Board, viewed 01 March 2006, from http://www.fasb.org/ brrp/brrp1.shtml

Harrington, G. \& Badian, L., 2009, Corporate websites: Best practices for website disclosure, MZ Bulletin, viewed March 2010, from http://www.google.com/ url?sa $=t \&$. source $=$ web $\& c d=8 \&$ ved $=0 C E I Q F j A H \&$ url $=h t t p \% 3 A \% 2 F \% 2$ Farnoldporte rllp.com\%2Fresources\%2Fdocuments\%2FArnold\%26PorterLLP MZBulletin 2009. pdf\& $r c t=j \& q=\% 22$ corporate $\% 20$ websites $33 \% 20$ best $\% 20$ practices $\% 22 \% 20$ harrington\&ei=iJ14TeSBIpSq8QPCXC3EBA\&usg=AFQjCNGxiQ7M2xivgUc1D9u1tfSA7QepQ\&cad=rja

Internet World Stats, 2010, Internet World Stats, viewed 01 February 2010, from http://www.internetworldstats.com/stats.htm

Investor Relations Marketing, 2006, Investor Relations Website Design, viewed 01 March 2006, from http://www.investorrelationsmarketing.com

Investor Relations Society, 2006, viewed 01 May 2007, from http://www.ir-soc.org.uk

Investor Relations Society, 2006, Website guidelines: Setting the standard for best practice in investor communications, viewed 01 May 2007, from http://www. irsoc.org.uk/index.asp?pageid $=87$

Jones, D., 2008, SEC survey a reality check on retail investor web use, viewed 01 February 2010, from http://www.irwebreport.com/daily/2008/08/06/sec-surveya-reality-check-on-retail-investor-web-use/

Loxton, L., 2003, 'Beleggersverhoudinge op die Internet: 'n Ondersoek in Suid-Afrika' [Investor relationships on the Internet: a Study in South Africa], Meditari 11, 81-
93, viewed 30 March 2010, from http://www.meditari.org.za/docs/2003/81_93. pdf

Makinson Cowell, 2000, Investor Relations Websites Expectation and Reality, viewed 01 June 2006, from http://www.makinson-cowell.co.uk/mc/publications/

Marston, C., 1996, 'The organisation of the Investor Relations Function by Large UK Quoted Companies', Omega 24(4), 477-488. doi:10.1016/0305-0483(96)00015-1

Nel, G.F., 2004, 'Future of financial reporting on the Internet', South African Journal of Information Management June 2004, viewed 01 February 2006, from http:// www.sajim.co.za.

Online investors relations awards, 2009, viewed 01 February 2010, from http://www. africanir.com/2010/01/30/2009-online-investor-relations-awards-2/

Securities and Exchange Commission, 2008, SEC Report, viewed March 2010, from http://www.sec.gov/comments/s7-28-07/s72807-142-phone.pdf

Venter, J.M.P., 2002, 'A survey of current online reporting practices in South Africa', Meditari 10, 209-225, viewed March 2010, from http://www.meditari.org.za/ docs/2002/Venter - Meditari 2002_15_.pdf

World Bank, 2009, Annual Report, viewed 01 November 2009, from http://www. worldbank.org/ 